\title{
The Incidence of COVID-19 in Uzbekistan Geographical Aspects
}

Nilufar K.Komilova ${ }^{1 *}$, Ibragim X.Mamatkulov²

${ }^{1}$ Professor, department of Economic and Social Geography National University of Uzbekistan named after Mirzo Ulugbek 100174, 4 University Str., Tashkent, and Republic of Uzbekistan

${ }^{2}$ Professor, Deputy Director for Scientific Affairs of the Tashkent Research Institute of Vaccines and Serums, Doctor of Medical Sciences

\author{
Article History \\ Received: 07.02.2021 \\ Accepted: 19.02 .2021 \\ Published: 05.03.2021
}

Journal homepage:

https://www.easpublisher.com

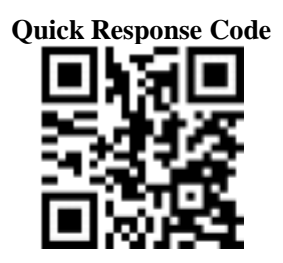

Abstract: Mankind has struggled with many diseases throughout its history. Infectious diseases are especially prevalent among the population. According to its scope, such infectious diseases are called pandemics, epidemics. Among the population of Central Asia, a number of diseases, such as plague, plague, malaria, tuberculosis, and ringworm, have caused partial or mass extinction. The characteristics of the geographical distribution of these diseases largely depended on the natural and social geographical conditions of the regions, the lifestyle and traditions of the population. The effects of the Spanish flu pandemic, which has killed nearly 100 million people in the last hundred years among a wide range of diseases, have had a profound effect on the nosogeographic situation, especially in Europe and later in the Americas. Analyzes show that the deterioration of the environment, man's unlimited domination of nature, the deterioration of the ecological situation, as well as the spread of related diseases on earth pose new challenges to medical geography, which studies the causes and patterns. The rapid development of science and technology, the steady increase in human impact on nature and consequently, a number of negative changes in the natural environment have a significant impact on human health. The acceleration of the process of urbanization which in turn causes problems such: as air, water and soil pollution.

Keywords: nosogeographic situation, human ecology, tuberculosis, malaria, pandemic, medical geography, plague rebellion, coronavirus infection, quarantine, xenophobia.

Copyright $(\mathcal{2 0 2 1}$ The Author(s): This is an open-access article distributed under the terms of the Creative Commons Attribution 4.0 International License (CC BY-NC 4.0) which permits unrestricted use, distribution, and reproduction in any medium for non-commercial use provided the original author and source are credited.

\section{INTRODUCTION}

Public health is one of the most important criteria for the development of any country. After all, health is an important condition and sign of society, social development.

When we compare the geography of different diseases or the nosogeographic situation, we see that the Central Asian countries, including the Republic of Uzbekistan, differ in their specific features.

As humanity enters the 21 st century, it is confronted with nosoecological conditions, new and new drugs and treatments that were and are not typical of previous periods. This is often explained by the growing globalization of the world economy and the steady growth of the population, the increasing pressure on people, urgency, and inactivity [1].

In the context of the globalization of the world economy and fierce competition, as well as the steady growth of the population, the number of deaths due to infectious and parasitic diseases is increasing. International organizations are also paying great attention to combating these problems and eliminating their consequences. In particular, the United Nations Program on Sustainable Development until 2030 addresses the issues of "eliminating epidemics of diseases such as AIDS, tuberculosis, malaria, as well as measures to combat hepatitis and other water-borne diseases by 2030." Special emphasis is placed. Successful implementation of these tasks requires the stabilization of nosoecological and nosogeographic conditions in arid climates [2].

The fact that some highly contagious diseases, which were reported to be completely extinct in the middle of the last century, are common among the population of some parts of the world, as well as the study of the geographical distribution of COVID-19 coronavirus infection, makes this issue extremely relevant. The implementation of these tasks poses important tasks not only for medical staff and the 
general public, but also for specialists in medical geography, who diagnose the existing diseases in the regions, i.e. the nosogeographic situation $\left[{ }^{1}\right]$.

It is known that a pandemic (Greek pandēmía, "whole nation") is a disease characterized by widespread epidemics that can spread not only in a particular country and some regions, but also in the border areas of several countries (Table 1). These include the Spanish flu, plague, swine flu, the COVID19 coronavirus pandemic, and three other plague pandemics known in history as the "black death" [3].

N.K.According to Kamilova, the first pandemic, the Justinian plague, was widespread in almost all Mediterranean countries, starting with Egypt, and lasted for almost 60 years. It is estimated that in 542 , more than 1,000 people died of the disease every day in Constantinople (Istanbul).

The second pandemic of the plague broke out in Europe in the summer of 1346, and it arose through traders from the east, especially China and India, in the process of delivering tea, and the disease caused thousands of corpses to become like coal. Massacres took place in Macedonia, Greece, Italy, the Mediterranean islands, then Spain and France, as well as Egypt, Libya and Syria. Even the Queen of Spain, the King of Aragon, the King of Castile, and the Queen of England were victims of this disease.

\section{Table-1: Pandemies}

\begin{tabular}{|c|c|}
\hline Pandemies & $\begin{array}{l}\text { - } \quad \text { Antonin plague }(165-180) \\
\text { - } \quad \text { Justinian plague }(541-750) \\
\text { - } \quad \text { Qaroolim (1346-1353) } \\
\text { - } \quad \text { The first plague pandemic }(1816-1826) \\
\text { - } 1837) \\
\text { The Third Plague Pandemic (1846- } \\
\text { 1860) } \\
\text { - } \quad \text { The Third Pandemic }(1855-1959) \\
\text { - } \quad \text { Tortinchipandemiya }(1863-1879) \\
\text { - } \quad \text { The Fifth Plague Pandemic }(1881-1896) \\
\text { The Sixth Plague Pandemic }(1899- \\
\text { - } \quad \text { Spanish flu (1918-1920) } \\
\text { - } \quad \text { Swine flu pandemic }(2009-2010) \\
\text { COVID-19 coronavirus pandemic } \\
\text { (starting in 2019) }\end{array}$ \\
\hline
\end{tabular}

Source: The table was compiled by the authors

1 Komilova, N. Kh., Turdimambetov, I. R, Ravshanov, A. Kh, Mahmudova, M. J, \& Payzieva, M.U.(2020) GEOGRAPHICAL ASPECTS OF THE STUDY OF GLOBAL PANDEMIES. European Journal of Molecular \& Clinical Medicine. Volume 07 , Issue 0,7 524-529
The third pandemic occurred in 1855 in Yunnan. 12 million people from China and India alone have died as a result of the disease.

Plague is an acute infectious quarantine disease of humans and animals, characterized by aggravation of the general condition, intoxication, fever, inflammation of the lymph nodes, lungs and other organs, and the development of sepsis. Due to the rapid spread of the disease and the death of many patients, the plague is one of the most dangerous diseases. The plague has long been known, and its epidemics have been frequent and fatal. Due to the plague, some areas were completely deserted. People who fled in order to get rid of it caused an epidemic in the new settlement [4].

The plague is said to be the most dangerous disease in human history in the last two thousand years. As a result of the "black plague", according to historical sources, $42 \%$ of the world's population at that time, or 200 million people, died. The plague, which spread during the reign of the Byzantine emperor Justinian I from 541 to 542 , killed 28.51 percent of the world's population, or 60 million people $\left[{ }^{2}\right]$.

One of these diseases is cholera, which is one of the most dangerous intestinal diseases, which is characterized by damage to the small intestine, intoxication, aggravation of the general condition and dehydration. Plague (1816) originated in the Ganges Valley in India; Due to the difficult living conditions there, part of the population began to move to other countries. As a result, the plague spread to Europe and later to the rest of the world, including Burma (1819), Java and Borneo, China (1820), Iran (1821), Japan, and Russia (1822). Between 1823 and 1925, plague epidemics were recorded 55 times in Russia. The plague spread to Turkestan, mainly through Afghanistan and Iran.

It should be noted that the plague uprising that took place in 1892 in connection with the plague can be said to have spread to Jizzakh in May 1892, and to Tashkent in June. 417 patients were identified in the new city and 1462 in the old city. Tsarist officials began to take urgent measures to prevent its catastrophic consequences: on June 7 , the city administration closed 12 old cemeteries and announced the opening of 4 new cemeteries, restricting access to the city. However, the colonial administration did not carry out explanatory work among the population and

2 Komilova, N.K., Ravshanov, A.K., Karshibaeva, L.K., Ishankulova, K.Q., \& Madrahimova, Z.N.(2020) Some theoretical and practical issues of medical geographical research. Indian Journal of Forensic Medicine and Toxicology. 14(3) 2086-2092. 
did not take into account Muslim customs and rituals. Instead of the promised four new cemeteries, only one has been opened. Those who died of the plague were ordered not to be buried without a doctor's permission, and it was forbidden to bury them in cemeteries in the city. Those who died of the disease were placed in the same grave as they had been buried in a deep grave, sprinkled with lime [4]. The uprising has been referred to in historical sources as the "Plague Rebellion" because of the spread of the plague and the government's response to it. Although quarantine rules have existed in Central Asia for a long time, we can see that they were first established in 1892 in Tashkent in connection with the "plague uprising". The Spanish flu which killed more people around the world in 1918 than even the First World War resulted in quarantine in many countries.

In the past, plague, smallpox, trachoma, malaria, leprosy, ringworm, and other infectious diseases were common among the population due to poor health care and poor living and working conditions. Poor living conditions in the country have led to an increase in mortality and a decline in life expectancy. In the past, the average life expectancy of the population of Uzbekistan was 32-33 years [3].

It should be noted that in his time, Ibn Sina worked on the treatment of diseases transmitted by microorganisms, bacteria and viruses, and to prevent it, the patient introduced into medicine a method of selfisolation for 40 days. Ibn Sina called this method "AlArba'in iyya". The word means "forty days." The method he introduced spread to Italy and all of Europe with the help of Venetian merchants. And the method of self-isolation was called "quarantine-quarantine", which means "forty" in Italian, and "quarantine" in English [5, $6]$.

Pythagoras who is the world's first philosopher linked quarantine and related ideas to the number 4 . That is, fire, air, water, and fire represent these elements as the basis of nature. By defining the plural form of 4 as 40 , he developed his own doctrine of numerical control of the world. If we look at the fact that Zoroastrianism, which played an important role in the ancient Eastern civilization, also holds the view that the four elements formed the basis of nature, we can see that this is not alien to our ancestors.

It is known that influenza is an infectious disease that is difficult to prevent because it can mutate four types of viruses and cause new epidemics. The first serious flu pandemic, called the Russian flu, began in 1889 , and in the 1990s it spread rapidly from the Eurasian steppes to Europe and America.
But the most horrific event was the second flu pandemic known as the Spanish flu. Its origins are unclear, dating back to World War I. In the United States, the virus mutates and causes death.

The military brings the disease to Europe, and by the end of World War I, it has spread around the planet. One-third of the world's population is infected with the disease, and about 50 million people die from the disease. There were two more flu pandemics, called the Asian flu in 1957 and the Hong Kong pandemic in 1968.

Today, the disease caused by a new type of coronavirus (COVID-19) is becoming more and more global. In a very short time, the infection spread from the epicenter of the disease - the city of Wuhan (China) to the rest of the world (Table 1). The pathogen is excreted through saliva particles when coughing and sneezing and can be transmitted to people within a 1.5-2 meter radius. In addition, it is possible to be infected by this or that object in the environment.

Today, we can see that the disease is on the rise in a number of countries around the world (Table 2 ). Coronaviruses are a group of viruses that cause diseases in mammals and birds, and in humans, viruses cause respiratory infections, which usually include mild infections, including colds; however, rare forms such as SARS, MERS, and new coronavirus can be fatal.

\section{The pandemic has caused a number of socio- economic challenges globally:}

- Caused the postponement or cancellation of sporting and cultural events;

- Concerns about shortages of medicines, electronics and food;

- Mortality has increased not only among the elderly, but also among the middle-aged and the younger generation.

The situation in the world. According to the latest data, as of February 2 this year, a total of 104480 575 patients were diagnosed with coronavirus infection in 221 countries, of which 76360610 (97\%) recovered, 2264877 (3\%) died, 107121 (0.4 percent) of patients remain in critical condition.

In the last day (02.02.2021y) 452,438 new cases were registered and 14,750 patients died from this disease. According to the World Health Organization, there are 27027430 cases of coronavirus infection in the United States, followed by India with 10778 206, Brazil with 9,286,256, Russia with 3884730 , and the fifth with confirmed cases. 3852623 cases were reported in the Great Britan, 3224798 in France and 2492977 in Turkey. 
Epidemic situation in neighboring countries and the Republic of Uzbekistan. Also from neighboring countries, 190359009 cases in the Republic of Kazakhstan ( +1228 cases per day), 84762 cases in the Kyrgyz Republic (+116 cases per day), 54062 cases in Afghanistan (+57 cases per day), and 13308 cases in Tajikistan ( no disease was reported in one day) $[7,8]$.

As of 7:00 on February 2, the number of coronavirus infections in the Republic of Uzbekistan was 78,859 , of which $77,333(98.0 \%)$ recovered and $621(0.8 \%)$ died.
Morbidity rates per 100,000 population. According to the World Health Organization, the Republic of Uzbekistan ranks 125th out of 221 countries in terms of morbidity per 100,000 population, Andorra ranks 1st, Montenegro ranks 2nd, the United States ranks 3rd, and Russia ranks 9th among neighboring countries., Kazakhstan ranks 106th. In terms of mortality, Uzbekistan ranks 150th, Portugal 1st, Montenegro 2nd, Andorra 3rd, Russia 8th and Kazakhstan 94th.

Table-2: Some information about COVID-19 in Uzbekistan (As of February 3, 2021)

\begin{tabular}{|l|c|c|c|}
\hline Areas & Recorded & Treated & The dead \\
\hline Respublic of Karakalpagistan & 869 & 859 & 6 \\
\hline Andijon & 2291 & 2270 & 2 \\
\hline Bukhara & 1476 & 1463 & 8 \\
\hline Jizzakh & 853 & 828 & 8 \\
\hline Qashqadarya & 1630 & 1613 & 16 \\
\hline Navai & 714 & 700 & 6 \\
\hline Namangan & 2719 & 2674 & 6 \\
\hline Samarqand & 2543 & 2505 & 7 \\
\hline Sirdarya & 1297 & 1293 & 2 \\
\hline Surxondarya & 1109 & 1095 & 8 \\
\hline Fergana & 875 & 855 & 2 \\
\hline Khorezm & 932 & 893 & 3 \\
\hline Tashkent & 15670 & 15261 & 129 \\
\hline Tashkent city & 45909 & 45024 & 418 \\
\hline Total & 78887 & 77333 & 621 \\
\hline
\end{tabular}

Data: Ministry of Health of Uzbekistan

\section{Level of testing[6].}

According to the level of testing

Gibraltar ranks 1st

The Faroe Islands are in 2nd place

Russia ranks 29th

Kazakhstan is in 66th place

Uzbekistan is on the 99th place

\section{The status of the "British" strain in the world}

According to the World Health Organization, the "British" strain of the coronavirus is registered in more than 70 countries. Flights with the Republic of Africa) have been suspended, and citizens coming from these countries through a third country are quarantined for 14 days. 10.
Identified in Uzbekistan on 30 January.

Activities carried out at state border checkpoints. On the basis of the statement of the Republican Special Commission, all citizens entering the territory of the Republic of Uzbekistan were tested for COVID-19 at the state border checkpoints. An average of 4000-6000 people enter the country every day from these points

According to the analysis of the laboratory, "positive" citizens are isolated and hospitalized in special infectious diseases hospitals.

It is observed that citizens with negative results at the state border checkpoints are then identified with "positive" results, which requires us to conduct a full and quality epidemiological survey on the ground. 


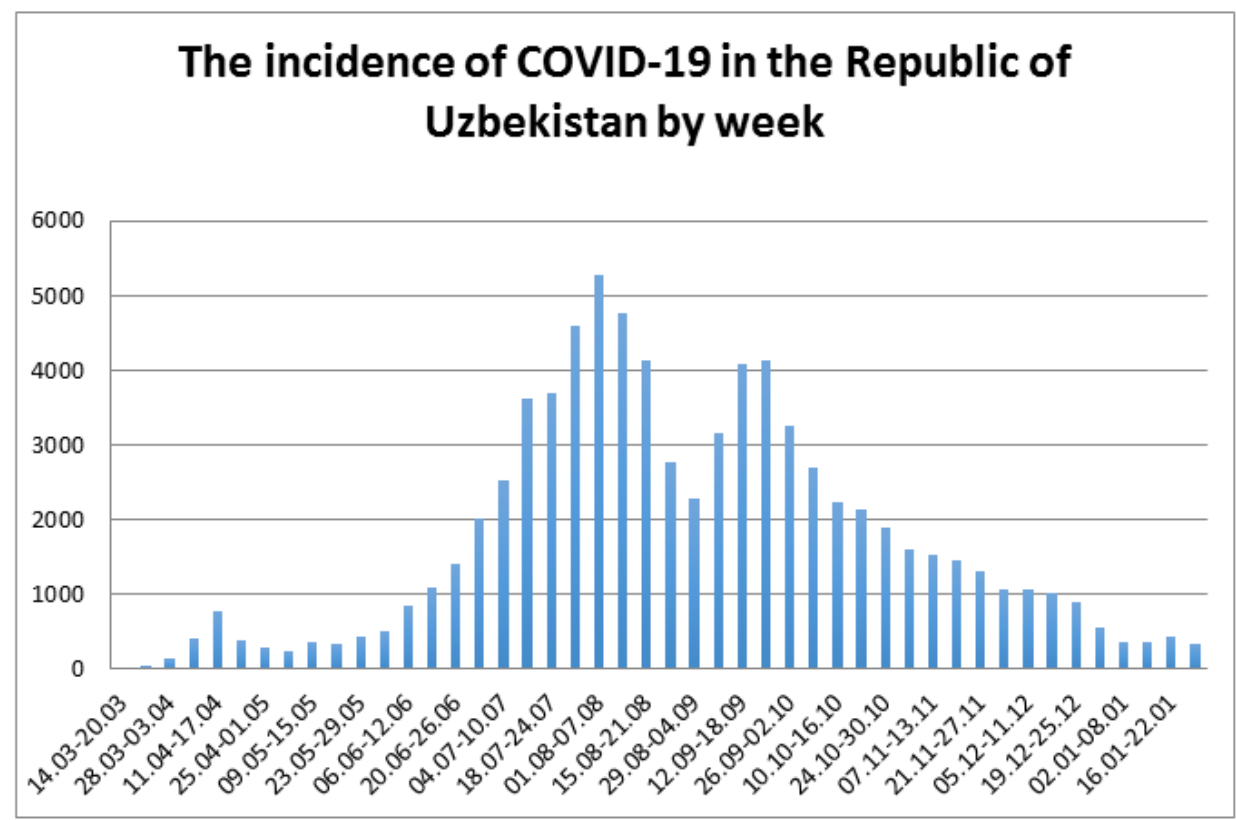

Fig-1

Data: Ministry of Health of Uzbekistan (As of February 3, 2021)

\section{Disadvantages}

- Epidemiological inquiries are very slow.

- The source of infection is detected in $10-15 \%$.

- Quarantine and control are poorly organized.

- No one deals with secondary and tertiary sources.
- Strict observance of quarantine requirements against new coronavirus infection by all medical and preventive institutions, schools and preschools, higher education institutions, as well as commercial and industrial enterprises in the country is weak.

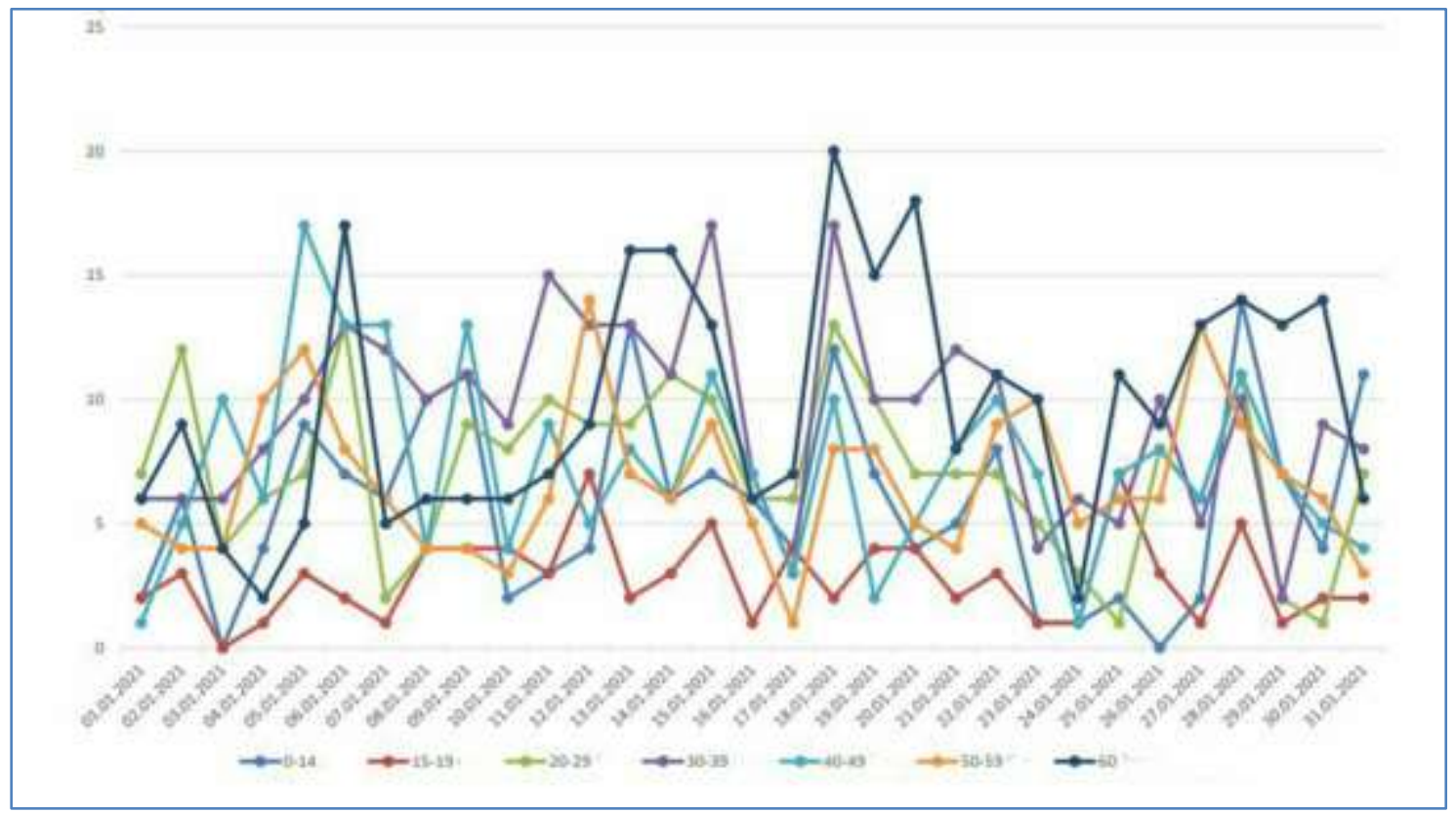

Fig-2

The age structure of the population is shown on the basis of colors. Data: Ministry of Health of Uzbekistan (As of February 3, 2021)

- Conditions of congestion on public transport, ie the presence of 2-3 times more passengers than the number of seats for each vehicle, but no control, no recommendations to the relevant organizations.
- Sanitary propaganda work on prevention of coronavirus infection among the population is weak.

Xenophobia has been observed in various countries, and panicked buyers have been seen buying large quantities of consumer goods. About this 
United Nations Secretary-General Antonio Guterres has warned of new coronavirus (covid-19) and an increase in hatred and xenophobia among communities.

If we compare the COVID-19 pandemic with the 25 pandemics of the last millennium, it is not even in the most deadly twenties. Therefore, we hope that modern medicine will achieve positive results in the treatment of this disease.

Experts point out that pandemics have undergone major changes in the fight against disease, such as public health, the economy, religion and social interactions, and the work process. "Life after a pandemic will never be the same as before," he said. The current pandemic (COVID 19) is no exception".

Among the measures we need to take in the future are:

- Carrying out epidemiological surveys at the required level;
- In the field, control of citizens from more than 70 countries where the "British" strain has been identified during the incubation period of the disease;

- In order to prevent cases of reinfection of "British" and "Asian" strains in the treatment and prevention facilities for coronavirus infection, separate patients according to the results of laboratory tests;

- Strengthen control over strict compliance with quarantine requirements against new coronavirus infection by all treatment and prevention facilities, schools and preschools, higher education institutions, as well as commercial and industrial enterprises in the country;

- Recommendations to relevant organizations in order to eliminate congestion on public transport;

- Carrying out a wide range of sanitary and advocacy work to prevent coronavirus infection among the population.

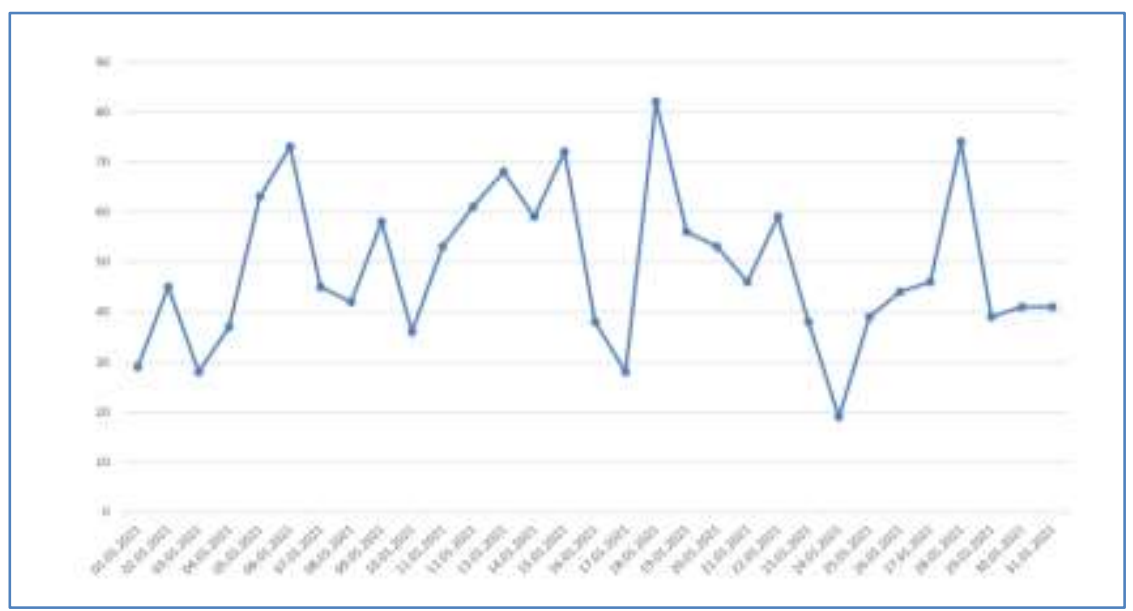

Fig-3: Dynamics of coronavirus in Uzbekistan (January total)

Data: Ministry of Health of Uzbekistan (As of February 3, 2021)

\section{CONCLUSION}

In conclusion, pandemics affect the demographic situation, the economy, and the mental and emotional well-being of the population, as well as the geographical distribution of countries in different countries and regions of the globe. However, in addition to the above negatives, we, as direct participants in the recent pandemic period, believe that the pandemic has strengthened the feelings of kindness, humanity, parenthood, and closeness to one's family; We can say that the value of life, life, health, is invaluable, and in this sense, we can say that in a sense, the pandemic educates humanity.

\section{REFERENCES}

1. Повестка дня в области устойчивого развития на период до 2030 года //Электронный доступ: http://www. uz.undp.org/content/Uzbekistan.ru
2. Komilova, N.K., Ravshanov, A.K., Karshibaeva, L.K., Ishankulova, K.Q., \& Madrahimova, Z.N.(2020). Some theoretical and practical issues of medical geographical research. Indian Journal of Forensic Medicine and Toxicology, 14(3) 20862092.

3. Komilova, N. Kh.,, Turdimambetov, I. R, Ravshanov, A. Kh, Mahmudova, M. J., \& Payzieva, M.U.(2020). Geographical aspects of the study of global pandemies. European Journal of Molecular \& Clinical Medicine, 7(7); 524-529

4. Karshiboyevna, K. N., Rakhmetovich, T. I., Xudoyberdiyevich, R. A., \& Juraevna, M. M. (2020). Geographical Aspects Of The Study Of Global Pandemies. European Journal of Molecular \& Clinical Medicine, 7(7), 524-529.

5. Komilova, N.K. (2020). Medical Geography and Global Health. Textbook. T .: "SHARQ", 
6. Komilova, N. K., \& Allanov, S. K. (2018). Medical and geographical aspects of the use of recreational resources. European science review, (9-10-1), 85-87.
7. Information of the Public Relations Department of the Ministry of Health of the Republic of Uzbekistan.

8. Data: Ministry of Health of Uzbekistan (As of February 3, 2021)

Cite This Article: Nilufar K.Komilova \& Ibragim X. Mamatkulov (2021). The Incidence of COVID-19 in Uzbekistan Geographical Aspects. EAS J Dent Oral Med, 3(2), 31-37. 